\title{
Non-adherence to hepatitis C treatment: a Brazilian report
}

\author{
Claudia Alexandra Pontes IVANTES ${ }^{1}$, Bernardo Carvalho da SILVA², Gabriel Gonçalves ACOSTA ${ }^{2}$, \\ Fabiane Beatriz Neves El TAWIL ${ }^{1}$ and Renato NISIHARA ${ }^{2}$
}

ABSTRACT - Background - In Brazil, since 2015, the treatment of hepatitis C is provided by SUS (Public Health System) with direct-acting antiviral (DAA). Objective - To describe the rate of non-adherence patients to hepatitis C treatment by DAA, investigating the epidemiological data in a large database from Curitiba, Brazil. Methods - Retrospective study with patients treated between January 2015 and June 2019. Patients were considered adherent when received all medication doses during their treatment. The following data were evaluated: gender, age, type of treatment, period of treatment, presence of diabetes or HIV, previous therapy, originated from SUS or private medicine, fibrosis grade and HCV genotype. Results - 1248 patients (56.8\% males) were studied and 102/1248 (8.2\%) were non-adherent to treatment. Age or gender not influenced significantly; $10.2 \%$ patients from SUS and 3.7\% individuals from private medicine were non-adherent $(P<0.0001 ; \mathrm{OR}=2.9 ; \mathrm{CI} 95 \%=1.6-9.1) ; 13.1 \%$ patients were co-infected with HIV and among them, $15.9 \%$ abandoned treatment. Individuals without co-infection presented $7.0 \%$ of non-adherence $(P<0.0001$; OR=2.5; $\mathrm{CI}=1.5-4.1)$. All the other variables showed no differences in the adhesion rate. Conclusion - Our study showed that $8.2 \%$ of patients were non-adherent to HCV treatment, and that patients from the Public Health System and co-infected with HIV were significantly less adherent.

Keywords - Hepatitis C; antiviral agents; patient compliance.

\section{INTRODUCTION}

Hepatitis $\mathrm{C}$ is an infection caused by the hepatitis $\mathrm{C}$ virus (HCV) that is transmitted through contact with contaminated blood. Is estimated that around 399,000 people/year will die from complications from Hepatitis $\mathrm{C}$ in the world ${ }^{(1)}$. It is a high prevalence disease worldwide, being present in all continents and with an estimate of approximately 71 million individuals affected in chronic phase ${ }^{(1)}$. From 1999 to 2018, 359.673 cases of hepatitis C were reported in Brazil. In the year of 2018, the highest virus detection rate, for both genders, was present in the age group between 55 to 59 years $\operatorname{old}^{(2)}$. The deaths associated with hepatitis $\mathrm{C}$ are the biggest among all other hepatitis in Brazil, and it has been reaching higher rates year after year. From 2000 to 2017, a total of 53,715 deaths were associated with hepatitis $\mathrm{C}^{(2)}$. In 2017, the mortality coefficient was 1.0 per 100,000 in the male population, while among females the coefficient corresponded to 0.7 per $100,000^{(2)}$.

In Curitiba, South Region of Brazil, the agency responsible for distributing medicines and counseling patients is the Center of Guidance and Advisor (COA), which works in prevention, diagnosis, and treatment of hepatitis C, all free of charge, provided by SUS (the Brazilian public health system), regardless if the patient had a private health care insurance or is a user of the public health system.

For a long time, hepatitis $\mathrm{C}$ treatment was carried out with the combination of $2 \mathrm{a}$ or $2 \mathrm{~b}$ alpha-pegylated interferon and ribavirin $(\mathrm{RBV})^{(3)}$. This treatment reported a cure rate of about $50 \%(20 \%$ in cirrhotic patients). However, patients showed many collateral effects and discomfort due to weekly injections for months, leading to low adherence to treatment. Since 2013, the Brazilian public health system incorporated three new direct-acting antivirals (sofosbuvir, simeprevir and daclatasvir) that combined and associated or not with RBV were used to treat individuals with hepatitis $C$. This treatment managed to reach levels close to $93 \%$ efficacy in sustained virological response (SVR), also largely reducing the adverse effects ${ }^{(3)}$. Patients who use this medication generally have few adverse effects, but there are still some individuals that are non-adherent and there are little data about the reasons that support this nonadherence. Knowing these reasons could improve the results of treatment and in the near future, eliminate hepatitis $\mathrm{C}$ in Brazil.

This study aimed to describe the rate of non-adherence patients to hepatitis $\mathrm{C}$ treatment by direct-acting agents, investigating the profile and epidemiological data registered in a large database from Curitiba, in the period from January 2015 to June 2019.

\section{METHODS}

This study was approved by the Ethics and Research Committee of the Prefeitura Municipal de Curitiba, under number CAAE 65272117.3.1001.0101.

This is a retrospective study, conducted in the database of hepatitis $\mathrm{C}$, attended and registered in the database of $\mathrm{COA}$ - Municipal Health Department of Curitiba, Brazil. In this study were included patients diagnosed with hepatitis $\mathrm{C}$ who received medication and follow-up by COA from January 2015 to June 2019. Patients whose data are not complete in the database have been excluded.

The following patient data were collected and analyzed: gender,

Declared conflict of interest of all authors: none

Disclosure of funding: no funding received

${ }^{1}$ Centro de Orientação e Aconselhamento (COA), Curitiba, PR, Brasil. ${ }^{2}$ Universidade Positivo, Departamento de Medicina, Curitiba, PR, Brasil.

Corresponding author: Renato Nisihara. E-mail: renatonisihara@up.edu.br 
age, type of treatment, date of beginning and end of treatment, period of treatment, presence of diabetes or HIV, previous therapy, originated from Public Health System (SUS) or private medicine, liver fibrosis grade, HCV genotype, and need of liver transplant. The treatment effectiveness was assessed by SVR 12 weeks after the end of treatment. The patients return each month, usually 4 days before finishing their medication, to receive a new prescription and withdraw your medicine free.

Patients were considered adherent when received all medication doses in COA during their treatment, which lasted for 12 or 24 weeks, depending on the treatment chosen by their physicians. Therefore, were considered non-adherent individuals that, for some reason, did not show up to get all the medicine doses in COA, or reported treatment interruption. Patients who died before treatment were not counted as adherent or non-adherent. Patients who died during treatment were considered non-adherent. Patients who died after the end of treatment, but sought all medications within the established deadlines were considered adherent. Patients who needed hospitalization for any reason and did not seek their medication during the established period were considered non-adherent.

The choice of 12 or 24 weeks of treatment is based on type of medication and patient's health condition according to the Brazilian Clinical Protocol and Therapeutic Guidelines ${ }^{(2)}$.

\section{Statistical analysis}

Distribution of numerical data was analyzed by the Shapiro Wilk test and central tendency was expressed in median and interquartile range (IQR). Nominal and categorical data were expressed in percentage (\%). Chi-squared and Fisher tests were used to compare male and female nominal data and the Mann Whitney test was used for numeric data. The adopted significance was $5 \%$.

\section{RESULTS}

From January 2015 to June 2019, 1248 patients (56.8\% males) received treatment at COA. TABLE 1 shows the demographic and clinical data on studied patients. In general, the mean age was $53.6 \pm 11.55$ years, being men significantly younger than women (51.2 \pm 10.74 and $56.4 \pm 11.97$ respectively, $P<0.0001)$. In addition, male patients were more affected by hepatitis $C$ than female patients $(\mathrm{OR}=1.7 ; \mathrm{CI} 95 \%=1.4-2.0)$.

A total of $102 / 1248(8.2 \%)$ of patients attended were considered non-adherent to treatment. Age or gender not influenced significantly ( $P=0.41$ and $P=0.16$, respectively) on adhesion to treatment. Data about non-adherent patients were in TABLE 1.

Comparing the adhesion rate between SUS or private medicine, $87 / 859(10.2 \%)$ patients from SUS were non-adherent and 15/406 $(3.7 \%)$ individuals from private medicine were considered nonadherent $(P<0.0001 ;$ OR $=2.9$; CI95\% $=1.6-9.1)$.

Regarding co-infection, 163/1248 (13.1\%) patients were coinfected with HIV and among them, 26/163 (15.9\%) abandoned treatment. Individuals without co-infection presented 76/1085 $(7.0 \%)$ of non-adherence. Thus, the rate of non-adherence was significantly higher in patients infected with $\operatorname{HIV}(P<0.0001 ; \mathrm{OR}=2.5$; $\mathrm{CI}=1.5-4.1)$. Among co-infected with HIV patients $75.1 \%$ were men and the gender not influenced in the adherence rate $(P=0.80)$.

Among the adherent patients, 12/1112 (1.1\%) deaths were observed and in non-adherent patients $8 / 102$ (7.8\%; $P<0.0001$; $\mathrm{OR}=8.4 ; \mathrm{CI} 95 \%=3.3-21.1)$. There is no difference in age or gender between patients who died in both groups.
In this sample, all liver transplant patients underwent surgery before starting treatment; therefore, this factor did not interfere on patients' adherence. In addition, previous treatment, presence of diabetes, grade of fibrosis, genotype of virus and type of treatment not influenced significantly the adherence rate.

\section{DISCUSSION}

Hepatitis $\mathrm{C}$ elimination requires widespread access to treatment and responses at health-service. Having knowledge about the profile of patients who abandoned treatment for hepatitis $\mathrm{C}$ is crucial for disease control strategies. This study, from a large database of patients attended in the capital of the state of South Brazil, showed that a rate of $8.2 \%$ of patients who started the treatment did not complete this purpose. In addition, co-infected patients and patients from the SUS were more susceptible to non-adherence to HCV treatment, and these factors increased the death risk significantly.

Epidemiological data about infected patients did not differ from other studies performed in $\mathrm{Brazil}^{(4,5)}$. Men were significantly more affected and younger than women. Predominantly were attended patients from SUS, being diabetes and HIV co-infection the main comorbidities. Data about liver fibrosis grade, genotype of virus, treatment and previous treatment is also similar to other reports ${ }^{(4,5)}$.

A major predictor of response to DAAs is adherence rate ${ }^{(6)}$. Therefore, the focus of this study is about non-adherence rate and to know the factors that influences this finding. The rate of $8.2 \%$ of non-adherence to HCV treatment can be considered high and worrisome. The objective is to eliminate hepatitis $\mathrm{C}$ in the world by $2030^{(6)}$. Although it tried, Brazil should not be able to achieve this goal and it is failing to test enough people mainly due to the SARS-COV 2 pandemic.

About treatment, nowadays the frequency of side effects and duration (12 or 24 weeks) of treatment are smaller than other previous therapy ${ }^{(7)}$. Our data showed that duration or type of drugs used as treatment did not influence significantly in the adherence rate, suggesting that both were well tolerated by the patients and did not contribute to improving the non-adherence rate ${ }^{(8,9)}$. In Brazil, since 2015, all the current drugs used as treatment to HCV are free of charge and available for the patients for both the public and private health systems. Monthly, they took the medication from a public pharmacy and were asked for side effects. However, the rate of non-adherence among patients from SUS is three times greater than private medicine. This finding suggests that socioeconomic status influence in the adherence to HCV treatment, as described by other authors ${ }^{(10)}$ and highlighted to a target population to follow-up the treatment. Gender and age did not influence the treatment's adherence.

In this study, among the patients co-infected with HIV, the rate of non-adherence was 2.5 greater than non co-infected. Lakshmi et al., in the United States, described that $11.9 \%$ of patients coinfected (HCV + HIV) were non-adherent to treatment and that $\mathrm{HCV}$ cure rates among co-infected patients seeking care in real world settings are lower than those reported in clinical trials ${ }^{(11)}$. Other authors described that the rate of HCV cure is similar in coinfected patients ${ }^{(12)}$. Some authors described reasons for lower adherence of these individuals to treatment such as type of treatment, frequency of clinic visits, depression, sociodemographic factors and others ${ }^{(11,13)}$. In addition, other authors reported that with the accessibility of HCV direct-acting antivirals, efficacy and adverse event rates among those with $\mathrm{HIV} / \mathrm{HCV}$ coinfection are 
TABLE 1. Clinical and demographical data of patients adherent and non-adherent to hepatitis $\mathrm{C}$ treatment with direct-acting antivirals.

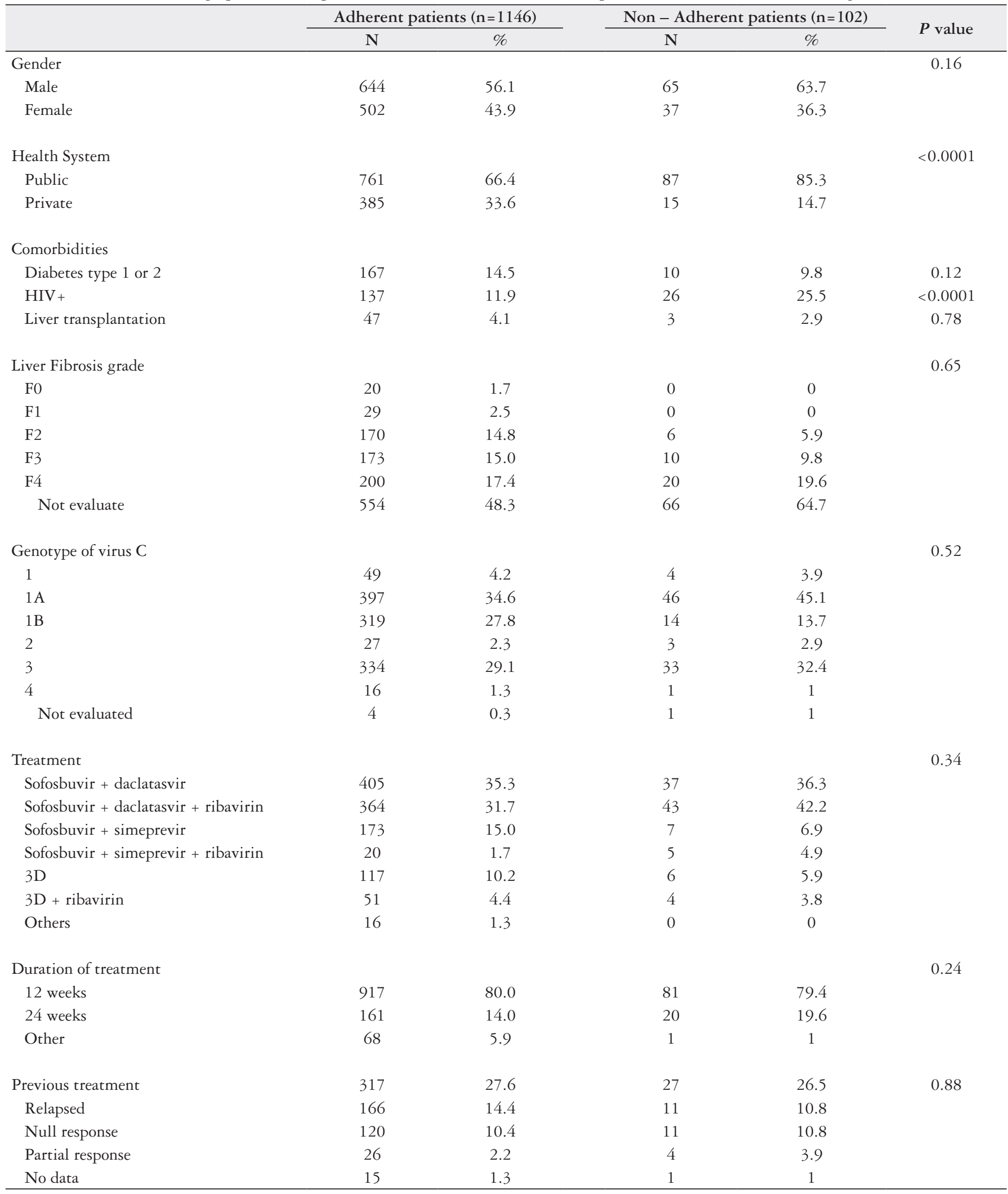

F0: absence of fibrosis; F1: portal fibrosis without septa; F2: portal fibrosis with few septa; F3: numerous septa without cirrhosis; F4: liver cirrhosis 3D: ombitasvir + veruprevir + ritonavir + dasabuvir 
similar to those observed with HCV monoinfection ${ }^{(14)}$. In our study, we did not find significant differences between types of treatment and, unfortunately, we do not have data about depression and socioeconomic status, therefore we believe that these factors probably influence adhesion rates. On the other hand, a prospective study with 74 marginalized patients from Canada ${ }^{(15)}$, showed that in the context of social marginalization and high rates of substance use, a community-based, supportive model of HCV treatment can promote high levels of adherence and achieve treatment outcomes that are comparable to registered clinical trials ${ }^{(15)}$.

Our data showed that the number of deaths among nonadherent patients was eight times higher than those adherent to treatment. Although it is expected, this data should be analyzed with caution, because many factors that were not possible to be evaluated could influence this finding.

Limitations of our study must be recognized, mainly due to retrospective design. We had no information on the socioeconomic status of subjects in our sample. Because lower socioeconomic status is associated with lower adherence to treatment, its omission may have biased to an unknown extent. It is possible that missing data does not actually reflect non-adherence and thus non-adherence may be overestimated in some cases. In addition, in this study the adherence rate was based on evidence of the drug being dispensed but not ingested.

Concluding, our study showed that $8.2 \%$ of patients were non-adherent to HCV infection treatment, and that the factors that significantly influenced this finding were patients in the Public Health System and co-infection with HIV.

\section{Authors' contribution}

Ivantes CAP, Silva BC, Acosta GG and Nisihara R conceived and carried out the study; Ivantes CAP, Silva BC, Tawil FBNE and Nisihara R organized and analyzed data. All authors were involved in writing the paper and had final approval of the submitted and published versions.

\section{Orcid}

Claudia Alexandra Pontes Ivantes: 0000-0001-5422-557X.

Bernardo Carvalho da Silva: 0000-0002-6797-1341.

Gabriel Gonçalves Acosta: 0000-0003-4267-1331.

Fabiane Beatriz Neves El Tawil: 0000-0002-5900-9056.

Renato Nisihara: 0000-0002-1234-8093.

Ivantes CAP, Silva BC, Acosta GG, Tawil FBNE, Nisihara R. Não aderência ao tratamento para hepatite C: um estudo brasileiro. Arq Gastroenterol. 2021;58(4):456-60.

RESUMO - Contexto - No Brasil, desde 2015, o tratamento da hepatite C é prestado pelo Sistema Público de Saúde (SUS) com antivirais de ação direta.

Objetivo - Avaliar a taxa de não adesão de pacientes ao tratamento da hepatite C pelo antiviral de ação direta investigando os dados epidemiológicos em um banco de dados de Curitiba, Brasil. Métodos - Estudo retrospectivo com pacientes atendidos entre janeiro de 2015 e junho de 2019 . Os pacientes foram considerados aderentes quando receberam todas as doses da medicação durante o tratamento. Foram avaliados os seguintes dados: sexo, idade, tipo de tratamento, tempo de tratamento, presença de diabetes ou HIV, terapia anterior, proveniente do SUS ou medicina privada, grau de fibrose e genótipo da hepatite C. Resultados - Um total de 1.248 pacientes (56,8\% homens) foram estudados e desses, $102 / 1248$ (8,2\%) não aderiram ao tratamento. Idade ou sexo não influenciou significativamente; $10,2 \%$ pacientes do SUS e $3,7 \%$ da medicina privada eram não aderentes $(P<0,0001$; $\mathrm{OR}=2,9$; IC95\%=1,6-9,1); 13,1\% dos pacientes foram coinfectados pelo HIV e, entre eles, $15,9 \%$ abandonaram o tratamento. Indivíduos sem coinfecção apresentaram 7,0\% de não adesão $(P<0,0001 ; \mathrm{OR}=2,5 ; \mathrm{IC}=1,5-4,1)$. Todas as outras variáveis não mostraram diferenças na taxa de adesão. Conclusão - Nosso estudo mostrou que $8,2 \%$ dos pacientes não aderiram ao tratamento para hepatite $\mathrm{C}$ e que os pacientes do SUS e coinfectados pelo HIV eram significativamente menos aderentes.

Palavras-chave - Hepatite C; agentes antivirais; cooperação do paciente.

\section{REFERENCES}

1. WHO - World Health Organization; Hepatitis C, 2020 - Available from: https:// www.who.int/news-room/fact-sheets/detail/hepatitis-c.

2. Brasil. Ministério da saúde; Boletim Epidemiológico de Hepatites Virais 2019 - Secretaria de Vigilância em Saúde - Ministério da saúde. Available from: http://pncq.org.br/uploads/boletim_hepatites_2019_c_.pdf. Last visited: $15 / 12 / 2020$

3. Ghany MG, Morgan TR, AASLD-IDSA Hepatitis C Guidance Panel. Hepatitis C Guidance 2019 Update: American Association for the Study of Liver Diseases-Infectious Diseases Society of America Recommendations for Testing, Managing, and Treating Hepatitis C Virus Infection. Hepatology. 2020;71:686721. doi: 10.1002/hep.31060.

4. Portari-Filho LH, Álvares-da-Silva MR, Gonzalez A, Ferreira AP, Villela-Nogueira CA, Mendes-Correa MC, et al. How are $\mathrm{HCV}$-infected patients being identified in Brazil: a multicenter study. Braz J Infect Dis. 2019;23:34-9. doi:10.1016/j. bjid.2019.01.006
5. Lobato CMO, Codes L, Silva GF, Souza AFM, Coelho HSM, Pedroso MLA, et al. Direct antiviral therapy for treatment of hepatitis C: A real-world study from Brazil. Ann Hepatol. 2019;18:849-54. doi:10.1016/j.aohep.2019.08.001.

6. WHO - World Health Organization. Towards the elimination of hepatitis B and C by 2030. Draft WHO Global Hepatitis Strategy, 2016-2021. Available from: https://www.who.int/hepatitis

7. European Association for the Study of the Liver. Electronic address: easloffice@ easloffice.eu; Clinical Practice Guidelines Panel: Chair: EASL Governing Board representative; Panel members. EASL recommendations on treatment of hepatitis C: Final update of the series. J Hepatol. 2020;73:1170-1218. doi: 10.1016/j. jhep.2020.08.018.

8. Falade-Nwulia O, Sutcliffe C, Moon J, Chander G, Wansom T, Keruly J, et al. High hepatitis $\mathrm{C}$ cure rates among black and nonblack human immunodeficiency virus-infected adults in an urban center. Hepatology. 2017;66:1402-12. doi:10.1002/hep. 29308 . 
9. Pecoraro V, Banzi R, Cariani E, Chester J, Villa E, D'Amico R, et al. New Direct-Acting Antivirals for the Treatment of Patients With Hepatitis C Virus Infection: A Systematic Review of Randomized Controlled Trials. J Clin Exp Hepatol. 2019;9:522-38. doi: 10.1016/j.jceh.2018.07.004

10. Luma HN, Eloumou SAFB, Noah DN, Eyenga BA, Nko'Ayissi G, Taku TS, et al. Hepatitis C Continuum of Care in a Treatment Center in Sub-Saharan Africa. J Clin Exp Hepatol. 2018;8:335-41. doi:10.1016/j.jceh.2018.01.001.

11. Lakshmi S, Alcaide M, Palacio AM, Shaikhomer M, Alexander AL, Gill-Wieh $\mathrm{G}$, et al. Improving HCV cure rates in HIV-coinfected patients - a real-world perspective. Am J Manag Care. 2016;22(6 Spec No.):SP198-SP204.

12. Milazzo L, Lai A, Calvi E, Ronzi P, Micheli V, Binda F, et al. Direct-acting an tivirals in hepatitis $\mathrm{C}$ virus (HCV)-infected and HCV/HIV-coinfected patients: real-life safety and efficacy. HIV Med. 2017;18:284-91. doi:10.1111/hiv.12429.
13. DiMatteo MR, Lepper HS, Croghan TW. Depression is a risk factor for noncompliance with medical treatment: meta-analysis of the effects of anxiety and depression on patient adherence. Arch Intern Med. 2000;160:2101-7. doi: 10.1001/ archinte.160.14.2101.

14. Rockstroh JK, Lacombe K, Viani RM, Orkin C, Wyles D, Luetkemeyer AF, et al. Efficacy and Safety of Glecaprevir/Pibrentasvir in Patients Coinfected With Hepatitis C Virus and Human Immunodeficiency Virus Type 1: The EXPEDITION-2 Study. Clin Infect Dis. 2018;67:1010-7. doi: 10.1093/cid/ciy220.

15. Mason K, Dodd Z, Guyton M, Tookey P, Lettner B, Matelski J, et al. Understanding real-world adherence in the directly acting antiviral era: A prospective evaluation of adherence among people with a history of drug use at a community-based program in Toronto, Canada. Int J Drug Policy. 2017;47:202-8. doi: 10.1016/j.drugpo.2017.05.025. 